\title{
GUILT AND LIABILITY BETWEEN ARISTOTLE AND STOICS
}

\author{
Tomáš Gábriš \\ Comenius University in Bratislava, Faculty of Law
}

\begin{abstract}
Cicero interpreted the Stoic term $\alpha \mu \alpha \rho \tau \eta \mu \alpha$, used already by Aristotle, as a "crime", thus coming to a seeming paradox of equality of all crimes, when explaining the Stoic claim of all $\dot{\alpha} \mu \alpha \rho \tau \eta \dot{\eta} \alpha \tau \alpha$ being equal. However, should the term refer rather to illegality or "guilt", all quotes become much less paradoxical. This seems even more appropriate in the context of responsibility for "killing one's father" mentioned in Stoic (and Aristotle's) treatises.
\end{abstract}

Key words: Aristotle; Stoics; Cicero; guilt; punishment; liability

\section{INTRODUCTION}

Both Aristotle's and Stoic's importance for later legal and philosophical thought is often emphasized in the literature, especially in the context of the school of natural law. ${ }^{1}$ Aristotle is invoked in this respect specifically with regard to the issues of free will and responsibility for one's own actions. ${ }^{2}$ In this paper we shall compare the approach of Aristotle and of Stoic philosophers to legal issues closely related to legal responsibility - questions of guilt and punishment. The link is going to take the form of notions $\dot{\alpha} \mu \dot{\alpha} \rho \tau \eta \mu \alpha$ and $\dot{\alpha} \mu \alpha \rho \tau i \alpha$, used by Aristotle as well as by Stoics, and they are even to be found in the New testament, albeitwith a slightly shifted meaning. It is thereby not without interest that according to Cicero, Stoics, unlike Aristotle, refused to distinguish between different kinds of wrongdoings $(\dot{\alpha} \mu \alpha \rho \tau \eta \dot{\mu} \alpha \tau \alpha$, peccata $)$ and different degrees of culpability. Cicero reports they proposed that punishment should only be based on consequences incurred and on motives of the perpetrator. ${ }^{3}$ This specific approach of Stoic philosophers to crime and punishment will be investigated here in greater detail, and our own explanation of the Stoic statement that "all wrongdoings are equal" will be proposed. Our proposed hypothesis is namely that Stoics employed the notion of $\dot{\alpha} \mu \alpha \dot{\alpha} \rho \tau \eta \mu \alpha$ in the modern sense of „guilt“.

\section{Wrongful conduct, guilt and punishment in the Aristotle}

Free will is a key factor of so-called negligence liability, taking into account the relationship of will of perpetrators to their conduct and to the outcome of their action. Should a person not dispose of

\footnotetext{
See BLITZ, M. Plato's political philosophy, p. 117

SORABJI, R. Necessity, Cause, and Blame: Perspectives on Aristotles's Theory, p. xiv. Aristotle could have influenced, for example, Justinian's concept of coactus volui (the forced person subsequently agreed with the action - Digest 4.2.21 (5)) and timor maioris malitatis (fear of a greater evil, similar to the extreme necessity - Digest 4. 2. 5). Ibid., p. 291, footnote 11. It is also believed that Aristotle influenced the Roman-Law-distinction into intent (dolus), negligence (culpa) and accident (casus). Ibid., p. 293. This is, however, called into question by David Daube - see IBBETSON, D. Wrongs and Responsibility in Pre-Roman Law. In The Journal of Legal History, pp. 99-127. Finally, Ulpian is reported in Digest to have stated - just like Aristotle - that an animal can not cause harm because it has no sense (Digest 9. 1. 1.3).

3 Stoic teaching is reconstructed mostly from Cicero's criticism of Stoics. See RIST, J. M. Stoická filosofie, pp. 90 et seq.
} 
free will, one could not freely decide on own actions and should thus never be held responsible for one's deeds; the actions would hence be considered as necessarily dependent (determined, conditional) upon circumstances outside the person itself.

The existence of free will, despite its general acceptance in legal scholarship as a fundamental principle of the accountability for one's own actions, currently seems to be disputed to a certain extent, based on experiments in the field of cognitive sciences - take e.g. the Libet experiment and related control experiments which have indicated that electric impulses in the brain associated with some physical activity precede the individual's will to act, thus questioning whether people are really conscious creators of their actions. ${ }^{4}$ However, even in this case, the scientists have come to a conclusion that humans still have some free will despite the experiments - namely, at least in the form of ability to control one's actions, respectively ability not to act - having free won't rather than free will. ${ }^{5}$

In contrast to the negligence liability (based on fault), there exists also a form of so-called strict liability, as a type of liability which is not based on free will or choice (and thus is a liability without fault), historically being considered an exceptional situation, resulting from specific social interests - particularly from the interest in protecting a weaker party standing in the position of victim/ harmed/injured person.

In this paper we shall examine first some Aristotle's insights into these problems - namely the issues of free will, fault and responsibility, and subsequently guilt and punishment - on the basis of his Nicomachean Ethics. This involves research at the intersection of philosophy and law, respectively within the broader scope of legal philosophy, which necessarily results from the fact that in the Nicomachean Ethics Aristotle apparently pays attention to these issues also from legal and judicial perspectives (as being "also useful to legislators regarding honors and punishments"). His conclusions will thereby partly be confronted with current legal approaches to these problems, despite being aware that such an approach might justly be considered anachronistic. ${ }^{7}$ Subsequently, Aristotle's views will be compared to those of Stoic philosophers, as reported by Cicero in his works, paying thereby closer attention to notions of $\dot{\alpha} \mu \dot{\alpha} \rho \tau \eta \mu \alpha$ and $\dot{\alpha} \mu \alpha \rho \tau i \alpha$ (translated by Cicero as peccatum) used both by Aristotle and Stoics, searching thereby for explanation of the Cicero's unclear account of Stoic theory of guilt and punishment.

\section{Free will in the Nicomachean Ethics}

The basic question of whether Aristotle recognized the existence of free will as a basic requirement for establishing fault, is often considered anachronistic. ${ }^{8}$ Still, even from among those who do not considere this issue anachronistic, one group of thinkers state that Aristotle expressly denies the concept of free will (as claimed e.g. by Cicero ${ }^{9}$ ), whereas other authors on the contrary argue for

BAYNE, T. Libet and the Case for Free Will Scepticism. In: SWINBURNE, R. (ed.) Free Will and Modern Science. See PYCHYL, T. A. Free Won't: It May Be All That We Have (or Need). Available at: https://www.psychologytoday.com/ blog/dont-delay/201106/free-wont-it-may-be-all-we-have-or-need (accessed on 22 September 2017).

ARISTOTLE. Nicomachean Ethics. Tr. C. D. C. Reeve, p. 35.

7 BARTLETT, R. C. - COLLINS, S. D. (eds.) Action and contemplation: studies in the moral and political thought of Aristotle, p. xii.

8 HUGHES, G. J. The Routledge guidebook to Aristotle's Nicomachean Ethics, p. 164. Hughes refers to several critics.

9 SORABJI, R. Necessity, Cause, and Blame: Perspectives on Aristotles's Theory, p. x. Free will in Aristotle is refuted also by SAUVÉ MEYER, S. Aristotle on the Voluntary. In: KRAUT, R. (ed.) The Blackwell guide to Aristotle's Nicomachean ethics, p. 138: "Rather than attributing freedom to agents, the "up to us" locution used by Aristotle implies causal responsibility." 
free will in Aristotle. ${ }^{10}$ Finally, a third opinion stream considers that Aristotle recognized free will only implicitly, when stating that everyone is free to choose how to act: "11 "Virtue too is up to us, then, and, similarly, vice. For where acting is up to us, so is not acting, and where saying "No" is up to us, so is saying "Yes." Hence if acting, when it is noble, is up to us, not acting, when it is shameful, will also be up to us. " (Nicomachean Ethics III.5). ${ }^{12}$ Hence, in Aristotle's example of a ship's captain who cast out during a storm the goods overboard in order to relief his boat, the captain was completely free to decide otherwise.

The concept of implicit or explicit recognition of free will by Aristotle will be an accepted basis of our further explanations here in this text. In our opinion, Aristotle namely clearly recognized the

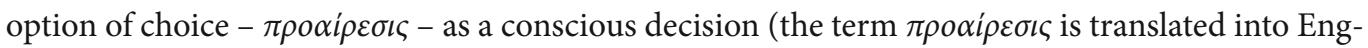
lish by different authors as "will", "act of will", "choice", "decision", "purpose”, or "intention" ${ }^{13}$ ). Should it not be possible to decide freely, we would have to deny that human being is "a starting-point or begetter of his actions as of his children." ${ }^{4}$

\section{Imputation of voluntary and involuntary actions in the Nicomachean Ethics}

A basic classification of human actions to be found in the third book of Nicomachean Ethics is their

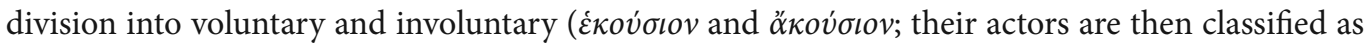
$\dot{\varepsilon} \kappa \omega \dot{\omega} v$ and $\left.\alpha \kappa \kappa \omega v^{15}\right)$. The difference between voluntary and involuntary actions thereby lies in the origin of cause of action - if the cause comes from within the actor, it is a voluntary action; if the cause comes from outside the actor, it is an involuntary action. Voluntariness and involuntariness are thereby drawn from the origin of the action - should it arise from within the actor, the action is voluntary; should it arise from outside the actor, the action is involuntary. Voluntariness and involuntariness thus have to do with the origin of the cause, being a characteristic trait of Aristotle's thought. ${ }^{16}$ The cause ( $\left.\dot{\alpha} \rho \chi \eta^{\prime}\right)$ was thereby seen by Aristotle in the originator (actor), should the originator knowingly (intentionally) give priority (within his choice - $\pi \rho \circ \alpha i \rho \varepsilon \sigma \iota \varsigma)$ to one action over another - usually based on the desire, ö $\rho \varepsilon \xi\left\llcorner\varsigma .{ }^{17}\right.$ Actions have namely two sources, claims Aristotle (in De Anima III.10) - reason (voṽ ) and desire (ős $\xi \varsigma),{ }^{18}$ whereby the reason (mind) itself does not move anything (Nicomachean Ethics VI.1).

According to Aristotle, therefore, an action which has its underlying cause in the actor and where the actor knows the circumstances of the action, is voluntary. In contrast, an action to which the

10 Alexander of Afrodisias in the $3^{\text {rd }}$ century BCE considered Aristotle to be indeterminist. See SORABJI, R. Necessity, Cause, and Blame: Perspectives on Aristotles's Theory, p. x. Freedom of will is seen in the works of Aristotle by PATOČKA, J. Platón a Evropa, p. 197.

11 For the third option advocates HUGHES, G. J. The Routledge guidebook to Aristotle's Nicomachean Ethics, pp. 165 and 167.

12 ARISTOTLE: Nicomachean Ethics. Tr. C. D. C. Reeve, p. 43.

13 PAKALUK, M. Aristotle's Nicomachean Ethics : An Introduction, p. 135.

14 ARISTOTLE: Nicomachean Ethics. Tr. C. D. C. Reeve, p. 43.

15 SAUVÉ MEYER, S. Aristotle on the Voluntary. In: KRAUT, R. (ed.) The Blackwell guide to Aristotle's Nicomachean ethics, p. 141.

16 RAPP, C. Free Will, Choice, and Responsibility (Book III.1-5 [1-7]). In HOFFE, O. (ed.) Aristotle's "Nicomachean ethics". Tr. D. Fernbach, pp. 89 et seq.

17 SAUVÉ MEYER, S. Aristotle on the Voluntary. In KRAUT, R. (ed.) The Blackwell guide to Aristotle's Nicomachean ethics, p. 101. See also ACKRILL, J. L. Aristotle on Action. In RORTY, A. O. Essays on Aristotle's Ethics, pp. 97-99.

18 DAHL, N. O. Aristotle on Action, Practical Reason, and Weakness of the Will. In ANAGNOSTOPOULOS, G. (ed.) A Companion to Aristotle, p. 498. 
person did not contribute in any way, and the cause of which is external, taking place against the will of the person, is involuntary. ${ }^{19}$ The latter situations are largely those dictated in particular by natural forces, such as being blown away by wind "what is forced is what has an external starting-point, that is, the sort of starting-point where the agent, or the one being affected, contributes nothing - as, for example, if the wind or human beings with control over him took him off somewhere." ${ }^{20}$ An action, not originating (rooting) in the person, i.e. an involuntary action, can be further internally divided into two different subspecies according to Aristotle. Here the element of will of the actor plays a certain role. One can thus discern, first, an involuntary action in the strict sense (for example, committed out of ignorance) being retrospectively regretted by the actor, and, second, a non-voluntary action, which is not being regretted by the actor, meaning that the actor subsequently accepted the outcomes of the action. Finally, according to Aristotle, there are also so-called mixed situations, including e.g. cases of coercion by tyrants - e.g. acting under the threat of death penalty against relatives of the actor. In such cases, although the actual action is essentially involuntary, it should overall be considered voluntary according to Aristotle, ${ }^{21}$ "on this occasion and done for these things". ${ }^{22}$

\section{Presumed liability?}

Does voluntariness or involuntariness affect in any way liability for one's actions? Let us pay attention to involuntary action first.

Aristotle does not claim in Nicomachean Ethics that involuntary action should automatically result in impunity. On the contrary, the liability was, apparently, arising also from involuntary actions (evoking perhaps our current notion of strict liability, regardless of fault/negligence). Each citizen was namely to behave and be able to control one's actions, otherwise the citizen would slip into a situation of ákpaбia ${ }^{23}$ and accept a sanction therefor, in the sense of communitarian citizenry, where the whole community is harmed by one's improper conduct. ${ }^{24}$ Verification of this argument can perhaps be found also in Plato's Laws (865-74): the Athenian $\pi$ ó ıৎ was namely - if the reading of Plato's Laws is correct - supposed to be tarnished by any wrongful act (disregarding its cause) and its cleansing was possible only upon making the offense good in the form of punishment or in providing for relevant compensation. ${ }^{25}$ Voluntariness or involuntariness itself might therefore exert no effect as to the rise of liability - the liability and obligation to provide compensation or to accept punishment arose in any case; liability was presumed. Voluntariness or involuntariness of action could perhaps serve only as an argument with respect to a type of punishment.

At this point it is appropriate to pay attention also to the problem of ignorance (lack of knowledge) and its role for considering an action voluntary, involuntary and for the emergence of liability in general. According to Aristotle, ignorance was to always have a consequence of action being

19 HEINAMAN, R. Voluntary, Involuntary, and Choice. In ANAGNOSTOPOULOS, G. (ed.) A Companion to Aristotle, p. 484.

20 ARISTOTLE. Nicomachean Ethics. Tr. C. D. C. Reeve, p. 35.

21 HEINAMAN, R. Voluntary, Involuntary, and Choice. In ANAGNOSTOPOULOS, G. (ed.) A Companion to Aristotle, p. 488.

22 ARISTOTLE. Nicomachean Ethics. Tr. C. D. C. Reeve, p. 36.

23 PRICE, A. W. Acrasia and Self-control. In KRAUT, R. (ed.) The Blackwell guide to Aristotle's Nicomachean ethics.

24 COLLINS, S. D. Aristotle and the Rediscovery of Citizenship, p. 40. On modern communitarianism see MACINTYRE, A. After Virtue: A Study in Moral Theory.

25 SORABJI, R. Necessity, Cause, and Blame: Perspectives on Aristotles's Theory, p. 289. 
considered involuntary, not having cause in the person of defendant. Ignorance could have thereby consist in any of six basic individual features of any action: the acting entity, action, object of the action, tool, methods, and outcome of the action. Ignorance in any of these individual items was automatically to have the consequence of being considered an involuntary action ${ }^{26}$ However, it is to be emphasized here again that involuntariness in itself did not exclude the emergence of liability nor of obligation to provide compensation (or accept punishment): "In fact, they also punish someone for ignorance itself, if he seems to be responsible for the ignorance - as, for example, when penalties are doubled in cases of drunkenness", "and similarly in other cases where someone seems to be ignorant because of neglectfulness, on the supposition that it is up to him not to be ignorant, since to take care was in his control." ${ }^{28}$ Thus it seems that even in case of an involuntary action due to ignorance, liability was presumed. The originator of the action could have then probably invoked an evidence demonstrating the ignorance and justifiable reasons for this ignorance.

In case of a voluntary action, the liability rules appear to have been even stricter. Aristotle namely

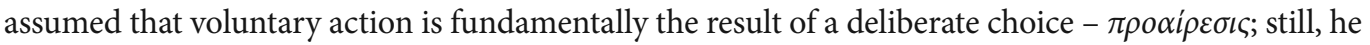
did recognize that morally weak people also act out of desire (ö $\rho \varepsilon \xi \iota \zeta)$ and volition ( $\beta o v ́ \lambda \eta \sigma \iota \zeta)$, or out of fear, ${ }^{29}$ and not by deliberate choice - on these grounds they are even sometimes acting against their own $\pi \rho о \alpha i \rho \varepsilon \sigma \iota \varsigma$, Aristotle claims. Nevertheless, legal consequences of such a situation have not been discussed by Aristotle. It may only be hypothecized that those circumstances were not to be taken into account by the judge, and this distinction by Aristotle was not to serve any legal purposes, but rather only non-legal, moral and ethical purposes, being subsequently used by Aristotle only in his analysis of the nature of man, thus in a non-legal context, ${ }^{30}$ having to do with the nature of human actions. ${ }^{31}$

Finally, under the Nicomachean Ethics, voluntary action was not only an action having its origin in the presumed deliberate $\pi \rho \circ \alpha i \rho \varepsilon \sigma l \varsigma$, but also a conduct originating in non-deliberate actions (such as sudden movements ${ }^{32}$ ), e.g. an action of a child or of a beast, where the possibility of deliberate choice was not recognized. ${ }^{33}$ However, Aristotle is silent here again on the important issues of how to assess such an action, and who should be held liable for the action. It is thereby likely that the originator of the action was to be held responsible, or the child's parents or beast owners respectively after all, it was a voluntary action, albeit lacking $\pi \rho$ oxi $\rho \varepsilon \sigma \iota$. This fact could have nevertheless been taken into account by judges in determining the amount or form of compensation or punishment.

In conclusion of his analysis, Aristotle finally comes to a synthesis here, and - depending on the type of action (origin of the cause) and liability for the actions - generally distinguishes between four types of wrongful actions. ${ }^{34}$ First, he distinguishes between two types of damage $(\beta \lambda \dot{\alpha} \beta \eta)$ caused

26 HEINAMAN, R. Voluntary, Involuntary, and Choice. In ANAGNOSTOPOULOS, G. (ed.) A Companion to Aristotle, p. 489.

27 ARISTOTLE. Nicomachean Ethics. Tr. C. D. C. Reeve, p. 44

28 Ibid.

29 SAUVÉ MEYER, S. Aristotle on the Voluntary. In KRAUT, R. (ed.) The Blackwell guide to Aristotle's Nicomachean

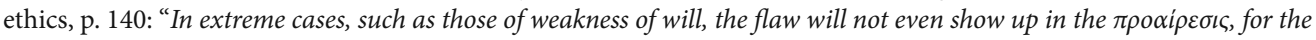

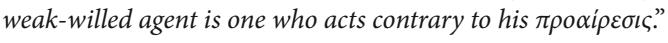

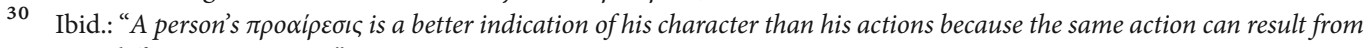

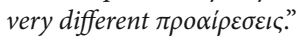

31 Ibid., p. 139: "The praiseworthiness of a disposition depends on the sort of activity it produces: "We praise the good person, as well as virtue, because of the actions and products..."."

32 ARISTOTLE. Nicomachean Ethics. Tr. C. D. C. Reeve, p. 38.

33 ROSS, D. - BROWN, L. The Nicomachean Ethics/Aristotle, p. 219.

34 SORABJI, R. Necessity, Cause, and Blame: Perspectives on Aristotles's Theory, pp. 278-279. 
involuntarily (i.e. caused by an external cause) - the first is an unlucky accident ( $\dot{\alpha} \tau \dot{v} \chi \eta \mu \alpha)$ where Aristotle again keeps silent on the liability issues; the second is a mistake ( $\dot{\alpha} \mu \dot{\alpha} \rho \tau \eta \mu \alpha)$ where the actor is to be held liable similarly as in case of acting out of ignorance (Nicomachean Ethics III, 5). Finally, the other two types of action are cases of voluntary action - $\dot{\alpha} \delta i \kappa \eta \mu \alpha,{ }^{35}$ differing from each other only in the seriousness of the offense (for example, that an action was not only a murder, but murder of one's own father ${ }^{36}$ ). In all four cases, intentional causation was presumed probably, but Aristotle is silent on this issue.

\section{Summary of Aristotle's perception of liability, guilt, and punishment}

Aristotle in the Nicomachean Ethics approached the issue of free will and liability in both legal and moral terms, which is explained by the fact that he acted as a tutor for the young members of Athenian elite.

Should we thereby accept that the Athenian $\pi$ dólৎ fundamentally presumed liability for any wrongful actions, the reason why Aristotle studied different forms of wrongful action might have been twofold - he could have tried to identify those cases where the originator of an action can nonetheless be liberated or have the punishment mitigated, or on the other hand, Aristotle could have studied these questions exclusively from the moral perspective. Most likely, however, is a combination of both reasons, in the spirit of the Aristotelian ideal of practical philosophy. ${ }^{37} \mathrm{~A}$ contingent by-product of the detailed elaboration of these issues was in any case an indisputable influence on future (including Stoic) jurisprudence and law-making, as we shall see below.

Hence, one may conclude that Aristotle in his treatise mostly presumed the liability of originator of an action. The actor, having free will, was to show excusable ignorance, or that the result did not have the cause in the actor at all.

\section{THE 'AMAPTIA and 'AMAPTHMA FROM HOMER TO NEW TESTAMENT}

We have seen previously that the notion $\dot{\alpha} \mu \dot{\alpha} \rho \tau \eta \mu \alpha$ (respectively in another form $\dot{\alpha} \mu \alpha \rho \tau i \alpha$ ) was used by Aristotle to denote an action that was a result of a mistake. It was therefore understood by Aristotle as denoting one type of misconduct, acting in error, respectively acting in ignorance. The same notion was later used by Stoics, and can also be found in the Bible (Greek New Testament), however, in both cases in a slightly shifted, more general sense. Translated into Latin as peccatum, this term also forms a basis of Cicero's criticism of Stoics, with Cicero claiming that for Stoics "all wrongdoings ( $\dot{\alpha} \mu \alpha \rho \tau \eta \dot{\mu} \mu \tau \alpha$, peccata) are equal". Prior to the analysis of Stoic understanding of liability, guilt, and punishment it is therefore necessary to closely analyse the said basic terms of $\dot{\alpha} \mu \alpha \rho \tau i \alpha$ and $\dot{\alpha} \mu \dot{\alpha} \rho \tau \eta \mu \alpha$ first.

David Ibbetson ${ }^{38}$ claims that at least since the times of Hugo Grotius (1583-1645), in Europe the term $\alpha \mu \alpha \dot{\alpha} \tau \tau \eta \alpha$ was considered a Greek equivalent of Roman legal term culpa (negligence), denot-

Ibid., p. 279

36 Ibid.

37 GADAMER, H.-G. The Idea of Good in Platonic-Aristotelian Philosophy, pp. 159 et seq.

38 IBBETSON, D. Wrongs and Responsibility in Pre-Roman Law. In The Journal of Legal History, pp. 99-100. 
ing a type of culpable action. For the earlier period, since around the third century CE, however, it is claimed that Roman culpa rather corresponded to Aristotle's term $\dot{\alpha} \delta i \kappa \eta \mu \alpha$, referring to a voluntary action. The $\dot{\alpha} \mu \dot{\alpha} \rho \tau \eta \mu \alpha$ was, in contrast, considered a term that referred only to acting in error, respectively in ignorance, being an involuntary action. This term was actually used in the meaning of acting in mistake already by Homer - specifically in the sense of missing in a javelin throw, and by Thucydides when referring to straying while being on a journey. ${ }^{39}$

Some authors therefore suggest that the notions of $\dot{\alpha} \mu \alpha \rho \tau i \alpha$ and $\dot{\alpha} \mu \dot{\alpha} \rho \tau \eta \mu \alpha$ could have actually had two meanings - one general, referring to wrongful conduct in general (meaning $\dot{\alpha} \mu \dot{\alpha} \rho \tau \eta \mu \alpha 1)$ and the other, more specific, used to describe a case of error or ignorance ( $\dot{\alpha} \mu \dot{\alpha} \rho \tau \eta \mu \alpha 2)$, which we have come across in the Nicomachean Ethics. ${ }^{40}$ This argument is supported by the use of this term in the broader meaning even by Aristotle himself in his Poetics - in connection with the tragedy and tragic actions of drama heroes, but also particularly by the use of the term $\dot{\alpha} \mu \alpha \rho \tau i \alpha$ in the Greek New Testament, where detailed textual analysis ${ }^{41}$ shows that it was used primarily to refer to $\sin$ in general, i.e. in the above-indicated broader meaning of $\dot{\alpha} \mu \dot{\alpha} \rho \tau \eta \mu \alpha$ 1. In 175 places within the New Testament, the term $\dot{\alpha} \mu \alpha \rho \tau i \alpha$ is namely translated into English as a "sin" (and in four other cases the term $\dot{\alpha} \mu \dot{\alpha} \rho \tau \eta \mu \alpha$ is translated as sin). In 23 other cases where the English translation uses the word "sin", original Greek text uses the term paraptoma which otherwise refers in Greek to trespassing the law, or committing an offense ${ }^{42}$ specifically, which evokes a more legalistic notion than $\dot{\alpha} \mu \alpha \rho \tau i \alpha$ or $\dot{\alpha} \mu \dot{\alpha} \rho \tau \eta \mu \alpha$ which are being used in the New Testament besides the "sin" rather to describe a situation of "missing a target", "failure or neglect", "erring, or doing wrong", ${ }^{43}$ hence not having a clearly legal meaning. Paraptoma in contrast, in general refers in the text of New Testament to a deliberate offense, or delict, and translates into English as follows: fall (twice), fault (twice), offense (7 times), sin (thrice) and trespass ( 9 times). ${ }^{44}$

Therefore, it seems that the term $\dot{\alpha} \mu \alpha \rho \tau i \alpha$, respectively $\dot{\alpha} \mu \dot{\alpha} \rho \tau \eta \mu \alpha$ could really be perceived as a term having two meanings - first, being used to describe a wrongful act in general, in the broadest (non-legal) meaning, whereby Aristotle borrowed this term from the general language identifying error, failure, and used it to designate a category of action in error, in ignorance, in the second, more narrow meaning. Then, New Testament translators (and probably also the Stoics) used this term again rather in the more general sense (in which it was probably used already in Aristotle's times, outside the Nicomachean Ethics) to label any "failure" or "wrongdoing".

\section{Wrongdoing, guilt, and punishment in the Stoic philosophy}

Trying to uncover the perception of wrongdoings, guilt, and punishment in the Stoic philosophy, we shall again start with the notions of $\dot{\alpha} \mu \alpha \rho \tau i \alpha$ and $\dot{\alpha} \mu \dot{\alpha} \rho \tau \eta \mu \alpha$. Since our source of knowledge on Stoic philosophy is foremost the classical works written by Cicero in Latin, one can encounter quite

39 MARTIN, R. P. Two Hundred New Testament Word Studies That Could Change Your Life, p. 184. Available at: https:// pioneernt.files.wordpress.com/2014/11/200-studies-corrected-10-2014.pdf (accessed on 22 September 2017).

40 LURJE, M. Die Suche nach der Schuld: Sophokles' Oedipus Rex, Aristoteles' Poetik und das Tragödienverständnis der Neuzeit. In: Beiträge zur Altertumskunde, p. 372.

41 MARTIN, R. P. Two Hundred New Testament Word Studies That Could Change Your Life, p. 184. Available at: https:// pioneernt.files.wordpress.com/2014/11/200-studies-corrected-10-2014.pdf (accessed on 22 September 2017).

42 Ibid., p. 8.

43 Ibid., p. 9.

44 Ibid. 
obviously rather the Latin term peccatum instead of the equivalent Greek term $\dot{\alpha} \mu \alpha \rho \tau i \alpha$ or $\dot{\alpha} \mu \dot{\alpha} \rho \tau \eta \mu \alpha$ (originally used by Stoics in place of peccatum). The Latin notion peccatum thereby immediately evokes the meaning of "sin" in Latin translations of New Testament, again pointing to the broader non-legal meaning of both the term $\dot{\alpha} \mu \alpha \dot{\alpha} \rho \tau \eta \mu \alpha$ as well as of peccatum.

Cicero offers a fairly accurate report on the understanding of the notion of peccatum in Stoics in a number of his works. In the following lines we shall, however, analyse only three of his works in this context - "Pro Murena", "Paradoxa Stoicorum" and "De finibus".

It is thereby specifically in the book "For Lucius Murena" where Cicero famously notes that, according to Stoics, "all wrongdoings are equal " (Pro Murena 62) - allegedly, even killing a rooster, if not necessary, is (can be) the same sort of wrongdoing (offense) as killing one's own father (Pro Murena 61). However, in the same section Cicero admits that Stoics nevertheless recognized there were different degrees of danger (severity) of offenses and various degrees of punishment (Pro Murena 63).

In the work called Paradoxes of Stoics, ${ }^{45}$ in the book III titled "That offenses are equal and good deeds are equal" in point 20 Cicero further develops the Stoic idea of offenses - the matter in which an offense was committed may indeed be more or less serious, however the offense is still the same, Stoics are reported to claim. According to Cicero, Stoics namely argue that an offense takes place in case of committing any prohibited conduct, and regardless of the severity of the offense there is always a violation present. So far so good, from today's point of view. Cicero also reports here that under Stoics, offenses should ultimately not be punished based on to the results of the action, but rather based on the nature (vices) of persons having committed the offenses - being recognized nowadays as well, when sanctioning repeat offenders. Therefore, according to Cicero, the Stoics recognize that an offense may consist in more serious or less serious conduct, and judges should asses these based on specific circumstances of the offender.

What confuses Cicero and what may confuse today's reader as well, is rather the already mentioned Stoic statement that all wrongdoings (offenses) are equal. However, should we accept that Stoics did not perceive the notion of "wrongdoing" ( $\dot{\alpha} \mu \dot{\alpha} \rho \tau \eta \mu \alpha$ ) as a "crime" but rather as a "misdeed, failure" (i.e. the original meaning of $\dot{\alpha} \mu \dot{\alpha} \rho \tau \eta \mu \alpha$ ), the Stoic statement would then not really mean equality of "crimes", but rather only equality of "illegality". This interpretation is not contradicted even by Cicero's account in Paradoxa stoicorum III.24 where he states that for Stoics, killing a father and a slave can show the same signs of "wrondoing" / "illegality", and in some cases even the same degree of severity (depending on the circumstances, respectively on the motive; whereby we deem the concept of "circumstances" to be more appropriate here than "motive" used by Cicero). In the point III.25, Cicero himself finally acknowledges that even for Stoics, actual difference existed between killing one's own father and a slave - namely he who killed one's own father, killed not only a man, but also killed an own relative at the same time, a person who raised him, who educated him, etc. Therefore, such an offender deserved stricter punishment even under Stoics. However, at the same time Cicero adds again that according to Stoics the punishment should not be imposed mechanically based only on the wrongful act, but also with regard to the offender - particularly in terms of taking into account the motives and other circumstances of the offense (as Aristotle did in the Nicomachean Ethics, see supra). At any rate, it seems correct that Stoics in general perceived any case of unlawfulness as being a conduct disturbing public order, and being illegal, regardless of

45 See WEBB, M.: Cicero's Paradoxa Stoicorum: A New Translation with Philosophical Commentary. Available at: https:// repositories.tdl.org/ttu-ir/bitstream/handle/2346/13953/31295003909982.pdf?sequence=1 (accessed on 22 September 2017). 
severity of the offense, as concluded by Cicero himself (Paradoxa Stoicorum III. 26). (And probably similarly recognized by Aristotle centuries before Cicero.)

Hence, our interpretation that Cicero's "wrongdoing" should not be understood as a "crime" but rather as "illegality" can ultimately be confirmed by a formulation found in Cicero's work De finibus III. $48,{ }^{46}$ where Cicero acknowledges that according to Stoics a "wrongdoing" does not have several degrees, but can be perceived as labelling more actions at once (hence, being a general, abstract notion).

\section{The á $\mu$ óprnua as a criminal "guilt"?}

The ancient Roman author Cicero apparently perceived equivalence of "wrongdoings" ( $\dot{\alpha} \mu \alpha \rho \tau \dot{\eta} \mu \alpha \tau \alpha$, peccata) as paradoxical. Indeed, as shown supra, this might be the case should we view "wrongdoing" as "crime" and not only as "illegality". However, according to John M. Rist, it could still be perfectly possible to hold in place even the meaning of "wrongdoing" as a "crime", without leading to a paradoxical situation, should we do so in the context of the original psychological doctrine of Stoics. Rist namely suggests that the "strangeness" of the Stoic doctrine of "wrongdoings" has its explanation in the older (in the days of Cicero already long abandoned) Stoic "monistic psychology," according to which no matter what degree of self-control one reaches, if not absolutely perfect, the person is still immature as far as it can not completely control oneself. ${ }^{47}$ This Stoic thought was based on an earlier idea that within the human pneuma (soul) there are waves which are running either arranged or as variables. Any "wrongdoing" was believed to cause instability of the waves, no matter how serious the "wrongdoing" was, explains Rist. ${ }^{48}$ At the same time, however, Rist himself notes that the Stoic term "wrongdoing" (in the Greek original $\alpha \mu \alpha \dot{\alpha} \rho \tau \eta \mu \alpha$ ) probably did not mean "crime" as interpreted by Cicero. Namely, according to Rist, when Stoics say that all $\dot{\alpha} \mu \alpha \rho \tau \dot{\eta} \mu \alpha \tau \alpha$ are equal (the same), instead of speaking of crime, $\dot{\alpha} \mu \dot{\alpha} \rho \tau \eta \mu \alpha$ was rather a notion denoting certain internal disposition of the actor, not external aspects of conduct. ${ }^{49}$ To some extent, we can agree with this interpretation, but our proposal to perceive $\dot{\alpha} \mu \alpha \dot{\alpha} \tau \tau \eta \mu \alpha$ as "illegality" does not match Rist's conclusions fully. While illegality is namely (to certain extent) an objective fact, Rist speaks only of internal aspects of wrongdoing. Therefore, at this point we shall try to accommodate our hypothesis on the meaning of $\dot{\alpha} \mu \dot{\alpha} \rho \tau \eta \mu \alpha$ by testing its possible meaning as "guilt", i.e. an obligation to suffer and accept punishment imposed by court. It is thereby not really an outer (external) relationship between a crime and an offender, but rather to a great extent also a situation of "inner disposition" of an offender with respect to the committed wrongdoing, solemnly declared by the court in the end of trial.

In order to test our interpretation of $\dot{\alpha} \mu \dot{\alpha} \rho \tau \eta \mu \alpha$ as a guilt, we shall now briefly go through the abovementioned Stoic ideas and reported statements to try to apply the newly proposed meaning of the term $\dot{\alpha} \mu \dot{\alpha} \rho \tau \eta \mu \alpha$ (peccatum) as a guilt.

In the first place, Stoics are claimed to recognize that punishment should be imposed not based on "guilt" ( $\dot{\alpha} \mu \dot{\alpha} \rho \tau \eta \mu \alpha)$, but rather based on the number of crimes (actions). ${ }^{50}$ Sanctions are therefore

46 CICERO, M. T. De finibus III. Available at: http://penelope.uchicago.edu/Thayer/E/Roman/Texts/Cicero/de_Finibus/3*. html (accessed on 22 September 2017)

47 RIST, J. M.: Stoická filosofie, p. 104.

48 Ibid., p. 99.

49 Ibid., p. 101.

50 Ibid., p. 91. 
not to be directly dependent on the "level of guilt"; anyone who commits a crime is namely "guilty" to the same extent; instead, it is motives and circumstances that are crucial for punishment - along with the type and number of crimes. ${ }^{51}$ "Guilt" can certainly not have any degrees in fact - it is either proclaimed by the court as being present or not, acknowledging under certain circumstances that even in case of a parricide the court may not find the perpetrator guilty. Thus, the Stoic claim seems to be upheld that $\dot{\alpha} \mu \alpha \dot{\alpha} \rho \tau \mu \alpha$ (read "guilt") is not determined by anything other than motive (and circumstances) ${ }^{52}$ Similarly, when Rist quotes from Stobaios, who claimed that "wrongdoings are equal but not similar, ${ }^{53}$ again this can be perceived as consistent with our interpretation of the equal "guilt" despite of different actions (and motives). Finally, our hypothesis can also be considered consistent with Rist's claim that $\dot{\alpha} \mu \dot{\alpha} \rho \tau \eta \mu \alpha$ should be an absolute and not a relative concept ${ }^{54}$ - considering someone "guilty" is namely without any doubt an absolute determination.

In our opinion, the outlined correlations between $\alpha \mu \alpha \dot{\alpha} \tau \tau \eta \mu \alpha$ in the sense of "guilt", and the Stoic concept of crime, motive, circumstances, and punishment in our above "test" viably correspond to what Cicero reports on Stoics and their teachings.

In conclusion, therefore, we offer for falsification our two-fold proposition that Stoic $\dot{\alpha} \mu \dot{\alpha} \rho \tau \eta \mu \alpha$ is distinct from "crime", and means either "wrongdoing/illegality" or "guilt", voiced in a judgment, which may be the case even if acting in error or ignorance, provided it is not a case of an excusable ignorance or a case specific in other circumstances and actor's motives. Should the Stoics have sought for a suitable Greek word to denote criminal "guilt", they might have found it in $\dot{\alpha} \mu \dot{\alpha} \rho \tau \eta \mu \alpha-$ given its broad meaning of "mistake" and "failure", suggesting a specific internal relation between an action and an actor, leading to liability and obligation to bear the consequences of the action. In the Christian doctrine, the same notion of $\dot{\alpha} \mu \dot{\alpha} \rho \tau \eta \mu \alpha$ could similarly have been later used as an appropriate denotation of sin - "evil deed", "failure", or even "guilt", as determined in the final instance by God - the supreme judge.

\section{CONCLUSION}

We have tried here to formulate some thoughts on philosophical approach to liability for illegal conduct starting from Aristotle and ending with Stoics. Both thereby has a tremendous effect upon later evolution of legal philosophy in Europe and in the Euro-Atlantic region in general. In our exposition, we have identified an interesting shift in the Greek notion of $\dot{\alpha} \mu \dot{\alpha} \rho \tau \eta \mu \alpha$, which the Greeks had employed since the times of Homer, and which was used in a specific legal meaning connected to liability already by Aristotle. Aristotle thereby used the notion in two different meanings - first to denote an action in error, and second, to denote any wrongdoing in general. Later, the meaning has even further shifted towards the meaning of a sin. Given the changing meaning and use of the word, we have proposed a new hypothesis on Stoic meaning of $\dot{\alpha} \mu \dot{\alpha} \rho \tau \eta \mu \alpha$. Cicero as a critic of Stoic paradoxes interpreted this term used by Stoics in the meaning close to that of "crime", thus coming to a seeming paradox of equality of all crimes. However, should we take the view that the term did not refer to "crime", but rather to "illegality/wrongdoing", or to a criminal "guilt" as a liability rela-

\footnotetext{
51 Ibid., p. 92.

52 Ibid., p. 90.

53 Ibid., p. 94.

54 Ibid., p. 93.
} 
tionship between an offense and the perpetrator, determined by a court, all Cicero's quotes from Stoic writings seem to gain a much clearer and less paradoxical meaning. Rist has proposed a similar operation prior to us, but he only claimed that the term $\dot{\alpha} \mu \dot{\alpha} \rho \tau \eta \mu \alpha$ should be perceived as "wrongdoing" instead of "crime", thus essentially gaining only moral significance. Albeit this interpretation can be accepted, we have nevertheless attempted to test also a hypothesis closer to the world of legal terminology and legal institutions, speaking of $\dot{\alpha} \mu \dot{\alpha} \rho \tau \eta \mu \alpha$ as "guilt". We consider this attempt as appropriate - taking the overall context of Cicero's reports on responsibility for "killing one's father" in Stoic treatises (and used as an example also in the Nicomachean Ethics).

\section{Bibliography:}

ACKRILL, J. L. Aristotle on Action. In: RORTY, A. O.: Essays on Aristotle’s Ethics. Berkeley : University of California Press, 1980.

ARISTOTLE. Nicomachean Ethics. Tr. C. D. C. Reeve. Indianapolis : Hackett Publishing Company, 2014.

BARTLETT, R. C. - COLLINS, S. D. (eds.) Action and contemplation : studies in the moral and political thought of Aristotle. Albany : State University of New York Press, 1999.

BAYNE, T. Libet and the Case for Free Will Scepticism. In: SWINBURNE, R. (ed.): Free Will and Modern Science. Oxford : Oxford University Press, 2011.

BLITZ, M. Plato's political philosophy. Baltimore: Johns Hopkins University Press, 2010.

CICERO, M. T. De finibus III. Available at: http://penelope.uchicago.edu/Thayer/E/Roman/Texts/Cicero/de_Finibus $/ 3^{\star}$. html (accessed on 22 September 2017).

CICERO, M. T. The Orations of Marcus Tullius Cicero. Tr. C. D. Yonge. London : Henry G. Bohn, 1856.

COLLINS, S. D. Aristotle and the Rediscovery of Citizenship. Cambridge : Cambridge University Press, 2006.

DAHL, N. O. Aristotle on Action, Practical Reason, and Weakness of the Will. In: ANAGNOSTOPOULOS, G. (ed.) A Companion to Aristotle. Oxford : Blackwell Publishing, 2009.

GADAMER, H.-G. The Idea of Good in Platonic-Aristotelian Philosophy. New Haven : Yale University Press, 1986.

HEINAMAN, R. Voluntary, Involuntary, and Choice. In: ANAGNOSTOPOULOS, G. (ed.): A Companion to Aristotle. Oxford : Blackwell Publishing, 2009.

HUGHES, G. J. The Routledge guidebook to Aristotle’s Nicomachean Ethics. Oxon : Routledge, 2013.

IBBETSON, D. Wrongs and Responsibility in Pre-Roman Law. In: The Journal of Legal History, 2004, 2, pp. 99-127.

LURJE, M. Die Suche nach der Schuld: Sophokles' Oedipus Rex, Aristoteles` Poetik und das Tragödienverständnis der Neuzeit. In: Beiträge zur Altertumskunde, Bd. 209. Berlin, New York : Walter de Gruyter, 2004.

MACINTYRE, A. After Virtue : A Study in Moral Theory. Notre Dame : University of Notre Dame Press, 1984.

MARTIN, R. P. Two Hundred New Testament Word Studies That Could Change Your Life. Available at: https://pioneernt.files.wordpress.com/2014/11/200-studies-corrected-10-2014.pdf (accessed on 22 September 2017).

PAKALUK, M. Aristotle's Nicomachean Ethics : An Introduction. Cambridge : Cambridge University Press, 2005.

PATOČKA, J. Platón a Evropa. Praha : Filosofia, 2007.

PRICE, A. W. Acrasia and Self-control. In: KRAUT, R. (ed.): The Blackwell guide to Aristotle's Nicomachean ethics. Oxford : Blackwell Publishing, 2006.

PYCHYL, T. A.: Free Won't: It May Be All That We Have (or Need). Available at: https://www.psychologytoday.com/ blog/dont-delay/201106/free-wont-it-may-be-all-we-have-or-need (accessed on 22 September 2017).

RAPP, C. Free Will, Choice, and Responsibility (Book III.1-5 [1-7]). In: HOFFE, O. (ed.): Aristotle’s „Nicomachean ethics“. Tr. D. Fernbach. Leiden : Brill, 2010.

RIST, J. M. Stoická filosofie. Praha : OIKOYMENH, 1998.

ROSS, D. - BROWN, L. The Nicomachean Ethics/Aristotle. Oxford : Oxford University Press, 2009. 
SAUVÉ MEYER, S. Aristotle on the Voluntary. In: KRAUT, R. (ed.): The Blackwell guide to Aristotle's Nicomachean ethics. Oxford : Blackwell Publishing, 2006.

SORABJI, R. Necessity, Cause, and Blame : Perspectives on Aristotles's Theory. New York : Cornell University Press, 1983.

WEBB, M. Cicero’s Paradoxa Stoicorum: A New Translation with Philosophical Commentary. Available at: https:// repositories.tdl.org/ttu-ir/bitstream/handle/2346/13953/31295003909982.pdf?sequence=1 (accessed on 22 September 2017).

\section{Contact information:}

doc. JUDr. PhDr. Tomáš Gábriš, PhD., LLM, MA

tomas.gabris@flaw.uniba.sk

Comenius University in Bratislava, Faculty of Law

Šafárikovo nám. č. 6

P. O. BOX 313

81000 Bratislava

Slovak Republic 